\title{
Radar Echo Structure of Middle-Level Precipitating Clouds and the Charge of Raindrops (II)
}

\section{-Change of Electrical Properties of Raindrops-}

\author{
By Yasushi Fujiyoshi* and Toshikatsu Takasugi** \\ * Water Research Institute, Nagoya University, Nagoya 464, Japan \\ ** Disaster Prevention Research Institute, Kyoto University, Kyoto 611, Japan \\ (Manuscript received 29 February 1980, in revised form 8 September 1980)
}

\begin{abstract}
Electrical properties of raindrops originated from middle-level precipitating clouds were studied on the basis of the simultaneous observations of the charge on raindrops and the structure of RHI radar echoes.

Main results are as follows: Raindrops with large positive charge were observed only when the intensive echo-regions in the streaks from generating cells passed over the site of observation. Except for the raindrops with large positive charge, large and small raindrops from middle-level clouds tended to be charged negatively and positively, respectively. The amount of charge on raindrops originated from warm rain clouds was smaller than that from middle-level clouds. It was inferred that the amount of charge on precipitation particles from middle-level clouds was not changed when the particles fell through low-level convective clouds.
\end{abstract}

\section{Introduction}

The electrical properties of raindrops-the amount and sign of charge-changed with time even in so-called continuous rain, which was mentioned previously (Fujiyoshi et al., 1980, hereafter referred to as paper I). Although many authors reported the change in the electrical properties of raindrops (for example, Smith, 1955; Magono and Orikasa, 1960), they had no data on the change in the structure of precipitating clouds. They only supposed the relation between the change of the electrical properties of raindrops and the structure of clouds. Simultaneous observation of electrical properties of raindrops and the structure of clouds would be necessary.

In paper I we reported the result of the simultaneous observation on the electrical properties of raindrops and on the structure of radar echo of middle-level clouds in which generating cells were contained. We suggested that most of precipitation particles formed in or near the centre of the updraught of the generating cells in the vigorous stage were charged positively and those originated from the cells in the decaying stage were charged negatively. We also suggested that when generating cells existed closely, the mixing of precipitation particles had the great effect on the clectrical properties of raindrops.

The main purpose of this paper is to discuss the change of the electrical properties of raindrops in association with the fine structure of middle-level clouds. Three cases described in this paper were observed from 22 to 23 June in 1977 in Owase of Kii Peninsula. Although all of three cases were related to middle-level clouds, the features of precipitation were different with one another as will be stated in the following chapters.

In paper I we used a vertically pointing radar to study the fine structure of clouds. In the present study a RHI radar of $3.2 \mathrm{~cm}$ in wave length was used so as to obtain much detailed information on the fine structure of clouds. Charge and size of raindrops, and atmospheric electric field were measured by using the same devices shown in paper $I$.

\section{Observational results}

2.1 CASE I (7.40 to 8.45 JST on 23 June) 

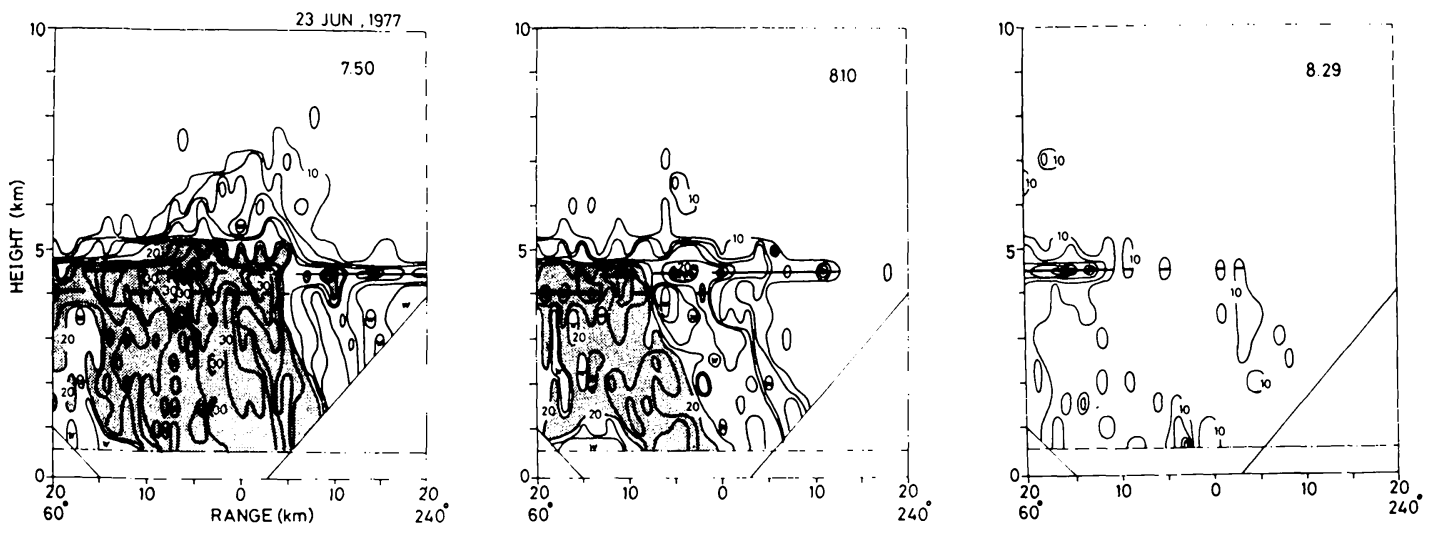

Fig. 1 Vertical cross sections of echo intensity for case I. Contours are drawn every 2 dBZ. A letter $w$ denotes that echo intensity is weaker there than in surrounding regions. Horizontal bars indicate the level of bright band. Areas where echo intensity is larger than $20 \mathrm{dBZ}$ are shaded.

The RHI radar was operated from 7.49 to 8.18. Fig. 1 shows the vertical cross sections of "echo intensity" which is defined as $10 \mathrm{Log} Z e$ (dBZ), where $Z e$ is equivalent radar reflectivity factor. The bright band appeared at about 4.5 $\mathrm{km}$ level. Echoes moved from right to left in Fig. 1. At 7:50 the echo-top defined by $10 \mathrm{dBZ}$ was higher around the radar site than the surroundings, and streaks with echo intensity larger than $30 \mathrm{dBZ}$ were observed in the region which had a high echo-top. The height of isopleth of the echo intensity fluctuated very often both spatially and temporally above the level of the bright band in the region which had a high echotop. These features of echo-pattern indicate that larger and/or more numerous particles existed at higher altitude around the radar site than the surroundings. The movie of the radar display showed the movement of radar echo, which suggested the presence of vertical air motion in the region with high echo-top above the bright band. The convective cells from which streaks emanate are called generating cells (Wexler and Atlas, 1959). The features written above indicate that the generating cells found above the radar site were still in the vigorous stage. The most intensive echo was observed at 7.58 at the site of observation. After 7.58 it rained lightly and stopped raining at 8.45 at the site.

Figs. $2 a, b, c, d$ and e show changes with time of surface electric field (E), positive and negative precipitation currents $\left(I_{\mathrm{pr} .}{ }^{+}\right.$and $\left.I_{\mathrm{pr} .}{ }^{-}\right)$, net precipitation current $\left(I_{\mathrm{pr} .}{ }^{\text {net}}\right)$, rainfall intensity $(R)$, and the flux of the positively and negatively charged raindrops per $\mathrm{cm}^{2},\left(n_{+}\right)$and $\left(n_{-}\right)$, and $\left(n_{+}-n_{-}\right)$, respectively. Surface electric field is called "positive" when its vector is pointing downwards (fair-weather case). Precipitation currents and rainfall intensity were averaged for every one minute. The surface electric field was between -300 and $-1,300 \mathrm{~V} / \mathrm{m}$. Both positive and negative precipitation currents which are defined in unit of $\mathrm{pA} / \mathrm{m}^{2}$ were larger between 7.40 and 8.00. Positive precipitation current was large from 7.55 to 8.00 when rather heavy rainfall was observed at the site of observation as seen in Figs. $2 b$ and $d$. Precipitation currents became small rapidly after 8.00. Although electric field was always negative, the sign of the net precipitation current changed with time.

Fig. 3 shows the charge-size distributions of raindrops. The ordinate denotes the diameter of raindrops $(D)$, and the abscissa denotes the positive or negative charge on raindrops averaged for one minute $\left(\bar{q}_{+}\right.$or $\left.\bar{q}_{-}\right)$. We divided the observational period into the following two periods:

(1) 7.40-8.00 JST; During the period rather intensive echoes passed over the radar site.

(2) 8.01-8.45 JST; During the period intensive echoes did not exist over the radar site.

It is seen from Fig. 3 that both the maximum diameter of drops and the largest amount of charge on drops observed during the period (1) were larger than those during the period (2). The attached numbers in Fig. 3 mean the time when the raindrops were observed. Raindrops with negative charge less than $-0.25 \mathrm{pC}$ were observed only between 7.47 and 7.50 , when rainfall intensity became weak as seen in Fig. 2d. Raindrops with positive charge larger than $+0.25 \mathrm{pC}$ were observed between 7.40 and 7.48 , and between 7.55 and 7.58 , when rainfall intensity was 
(a)

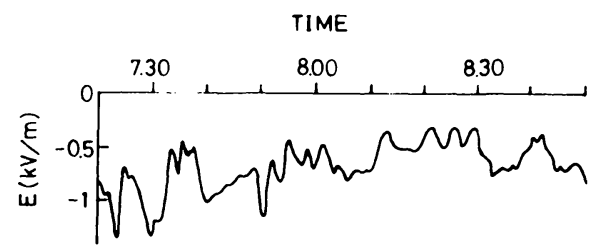

(b)

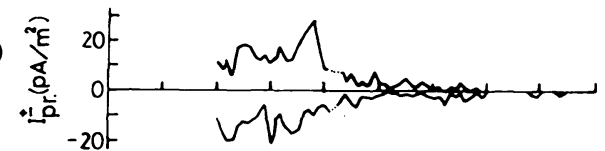

(c)

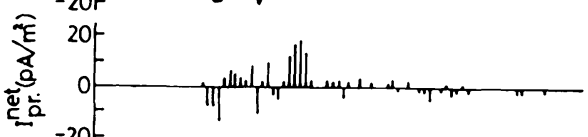

(e)

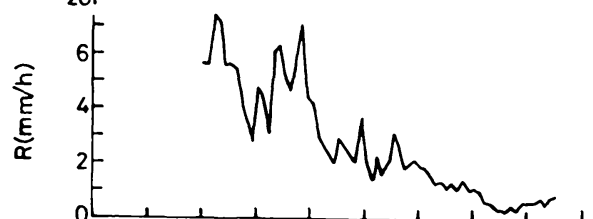

(d)

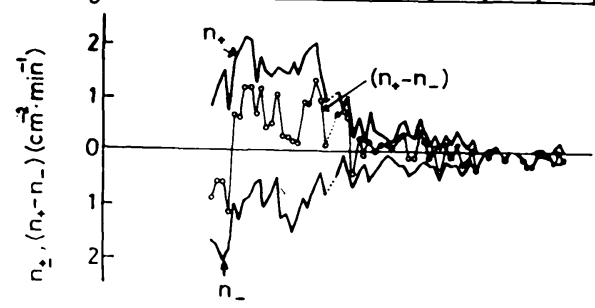

Fig. 2 Changes with time of (a) surface electric field (E), (b) positive and negative precipitation currents $\left(I_{\mathrm{pr} .}{ }^{ \pm}\right)$, (c) net precipitation current $\left(I_{\mathrm{pr} .}{ }^{\text {net}}\right)$, (d) rainfall intensity $(\mathrm{R})$, and (e) the flux of the positively and negatively charged raindrops per $\mathrm{cm}^{2},\left(n_{+}\right)$and $\left(n_{-}\right)$, and $\left(n_{+}-n_{-}\right)$.

large as seen in Fig. 2d. The diameter of raindrops with negative charge less than $-0.25 \mathrm{pC}$ was larger than $2.8 \mathrm{~mm}$, but positive charge larger than $+0.25 \mathrm{pC}$ was observed even for the raindrops with $0.8 \mathrm{~mm}$ in diameter. In other words, when the peak of rainfall from the generating cell appeared at the radar site, drops with large positive charge were observed for almost all sizeranges. After 8.00 when intensive echo-region had passed over the radar site, we did not observe raindrops with charge larger than $0.2 \mathrm{pC}$. The charge-size distribution of the raindrops with charge smaller than $0.25 \mathrm{pC}$ for the period between 7.40 and 8.00 was quite resemble the result obtained by Smith (1955). That is, the charge averaged for small drops were opposite in sign to that of electric field, while larger drops had

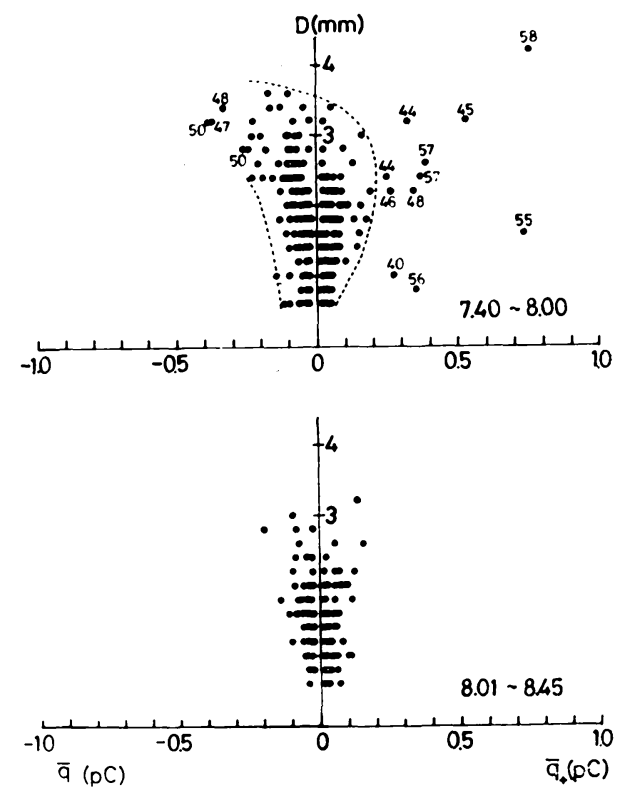

Fig. 3 Charge-size distributions of raindrops for case $I$. The attached numbers mean the time when the raindrops were o'sserved.
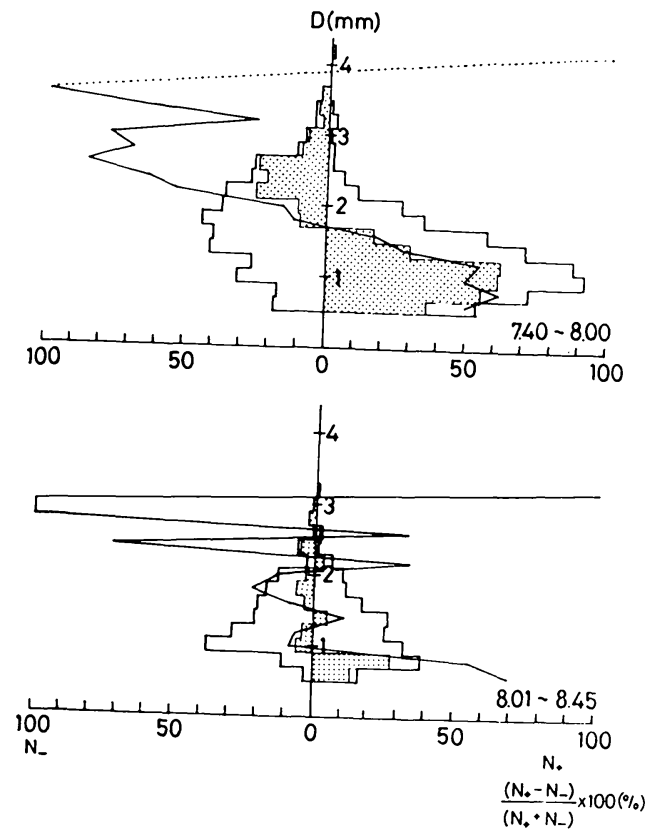

Fig. 4 Number-size distributions of raindrops for case I. The difference between numbers of positively and negatively charged drops is lightly shaded. Solid lines show the percentage of the difference to total numbers of charged raindrops. 
the charge of the same sign as surface electric field.

Kikuchi (1975) reported that the mirror image relation was settled between $\left(n_{+}-n_{-}\right)$and the surface electric field in case of snow clouds. As seen in Fig. 2e the flux of the positively charged raindrops $\left(n_{+}\right)$was larger than that of the negatively charged ones $\left(n_{-}\right)$from 7.44 to 8.00 under negative electric field, when it rained heavily. Fig. 4 shows the number-size distributions of raindrops. The ordinate denotes the diameter of raindrops $(D)$, and the abscissa denotes the number of positively or negatively charged raindrops which were sampled on the area of $16 \mathrm{~cm}^{2}$ $\left(N_{+}\right.$or $\left.N_{-}\right)$. The difference between both numbers $\left(N_{+}-N_{-}\right)$is lightly shaded. Solid line in Fig. 4 shows the percentage of the difference to total numbers of charged raindrops which is defined to be

$$
\begin{aligned}
& \left\{N_{+} /\left(N_{+}+N_{-}\right)\right\} \times 100(\%) \\
& \quad-\left\{N_{-} /\left(N_{+}+N_{-}\right)\right\} \times 100(\%) .
\end{aligned}
$$

It is seen in Fig. 4 that most of raindrops larger than $1.6 \mathrm{~mm}$ in diameter were charged negatively and most of drops smaller than $1.6 \mathrm{~mm}$ were charged positively between 7.40 and 8.00. On the other hand, $N_{+}$was nearly the same with $N_{-}$ for drops larger than $1.0 \mathrm{~mm}$ and $N_{+}$was larger than $N_{-}$for drops smaller than $1.0 \mathrm{~mm}$ betwcen 8.01 and 8.45 .

\subsection{CASE II (14.11 to 15.25 JST on 22 June)}

Fig. 5 shows the vertical cross sections of echo intensity. As seen in Fig. 5a, precipitation particles did not yet reach the ground around the radar site until 14.11. The echo-base had a stalactitic appearance, which implies the evaporation of precipitation particles (Harris, 1977). This type of echo often appeares in northern part of a warm front. Bowen (1951) concluded that such an echo is due to the spontaneous freezing of relatively large drops in the cloud. These freezing particles would grow by processes of sublimation and aggregation during their fall. The bright band is seen at about $3 \mathrm{~km}$ level in Figs. $5 \mathrm{~b}$ and c. Echoes whose echo-base had already reached

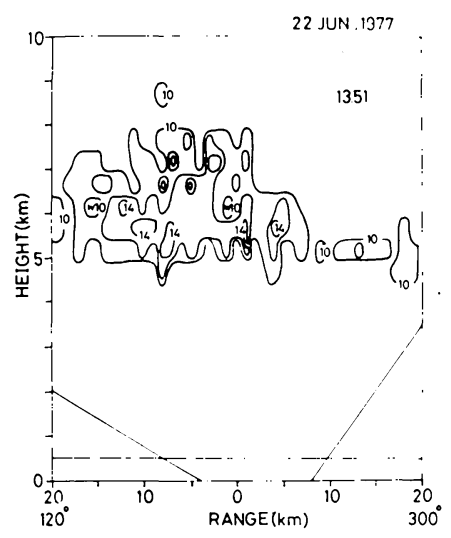

(a)

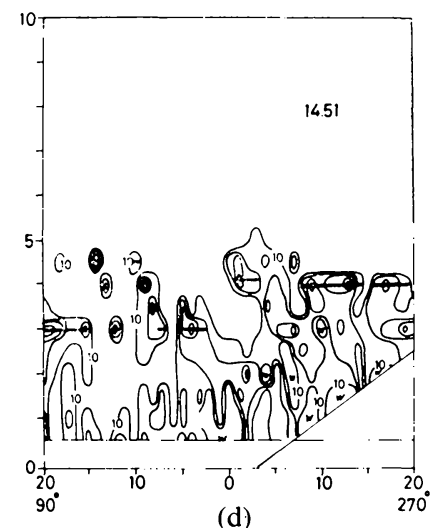

(d)

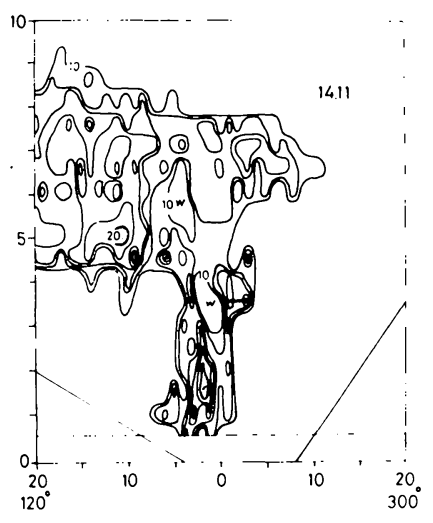

(b)

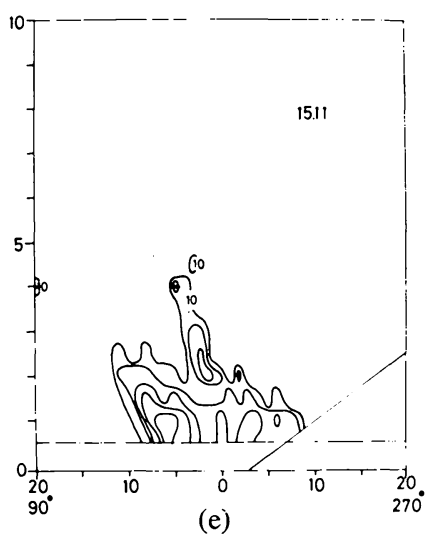

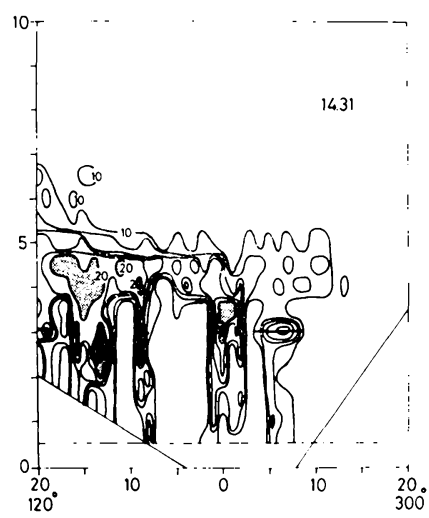

(c)

Fig. 5 Vertical cross sections of echo intensity for case II. 
the ground are seen in the right part of Fig. $5 \mathrm{~d}$. They moved to the left and passed over the radar site after 14.52. The height of echo-top defined by $10 \mathrm{dBZ}$, which was at about $5 \mathrm{~km} \mathrm{level,} \mathrm{was}$ rather constant until the echoes reached the radar site, but they dissipated rapidly during the passage over the radar site. Raindrops observed after 14.52 are suggested to have been originated from the generating cells which were in transition from mature stage to decaying stage. It is interesting that the bright band appeared at about 4.0-4.5 $\mathrm{km}$ level, though the bright band was found at lower level in Figs. $5 b$ and c. More detailed discussion on the structure of these echoes, especially on bright bands appeared at two different altitudes, was done in another paper

(a)

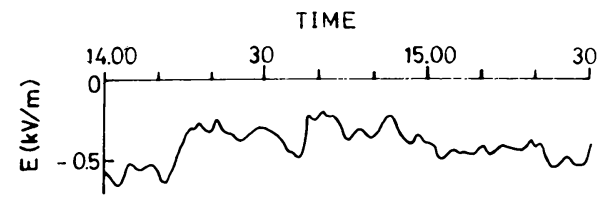

(b)

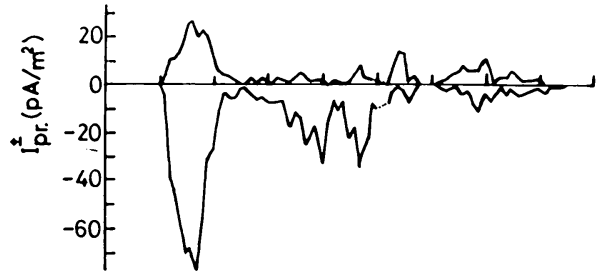

(c)

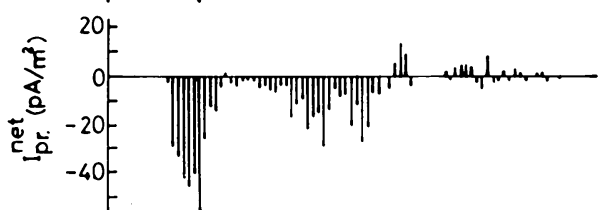

(d)

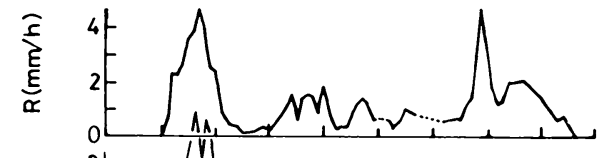

(e)

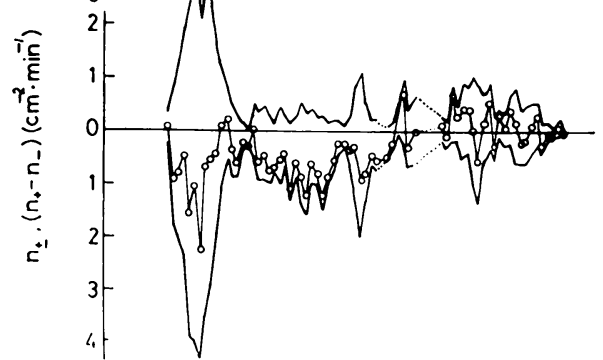

Fig. 6 Changes with time of (a) surface electric field, (b) positive and negative precipitation currents, (c) net precipitation current, (d) rainfall intensity, and (e) the flux of the positively and negatively charged raindrops per $\mathrm{cm}^{2}$.
(Fujiyoshi and Takeda, 1980).

Figs. 6a, b, c, d and e show changes with time of $E, I_{\mathrm{pr} .}{ }^{ \pm}, I_{\mathrm{pr} .}{ }^{\text {net }}, R$, and $\left(n_{ \pm}, n_{+}-n_{-}\right)$, respectively. The surface electric field was between -130 and $-700 \mathrm{~V} / \mathrm{m}$. The sign of net precipitation current was negative before 14.51, while it changed with time after 14.51. Both positive and negative precipitation currents were large between 14.10 and 14.20. Although negative precipitation current was rather large, positive precipitation current was small between 14.20 and 14.51 .

The charge-size distributions of raindrops for three periods (14.11-14.22, 14.23-14.50 and 14.52-15.25) are shown in Fig. 7. Large raindrops were charged negatively in the negative electric field between 14.11 and 14.22, and between 14.23 and 14.50. This tendency is extremely similar to the result obtained by Smith (1955). On the contrary, large raindrops were observed to be charged positively under negative electric field between 14.52 and 15.25. Raindrops obtained from 14.11 to 14.50 were observed when the base of the stalactitic echo reached the ground, and those between 14.52 and 15.25 were originated from another type of middle-level clouds as shown in Fig. 5. The attached numbers in Fig. 7 mean the time when the raindrops
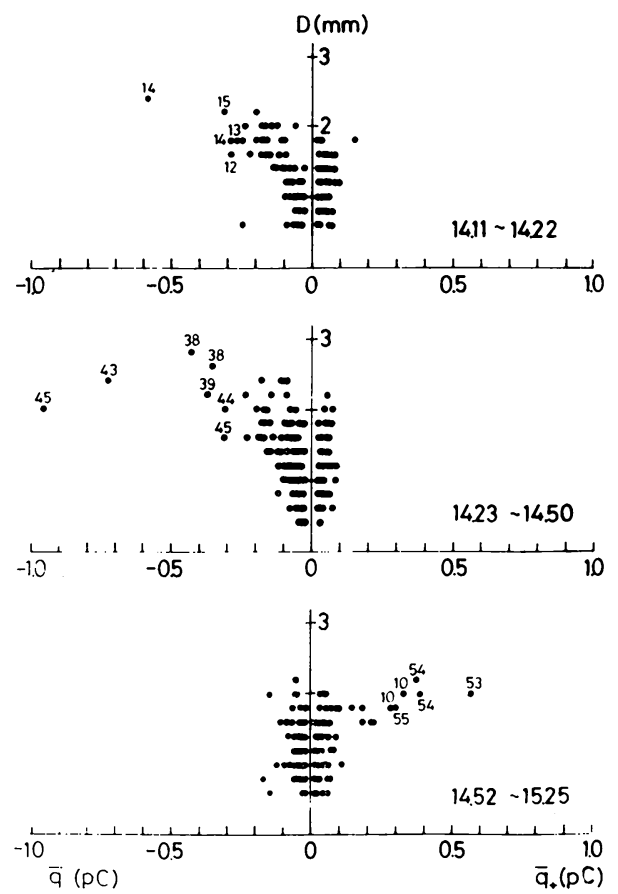

Fig. 7 Charge-size distributions of raindrops for case II. 


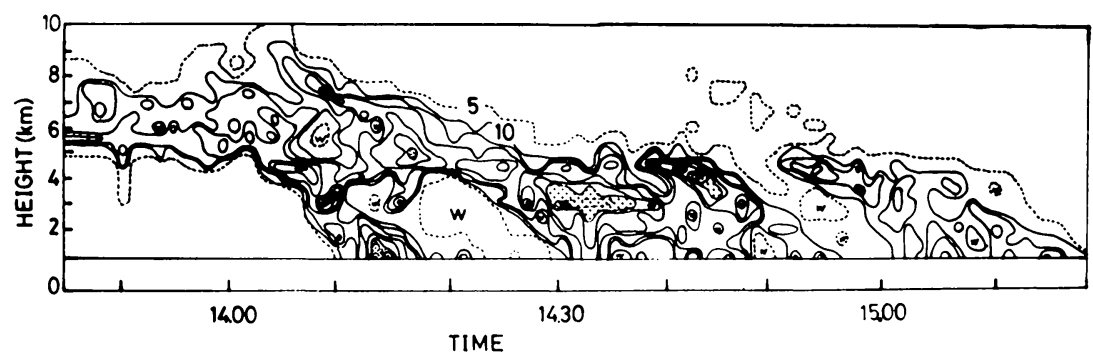

Fig. 8 Time-height cross section of echo intensity at the radar site.

with charge larger than $0.25 \mathrm{pC}$ were observed. During the period between 14.11 and 14.22 the raindrops with charge larger than $+0.25 \mathrm{pC}$ were not observed, and the charge less than $-0.25 \mathrm{pC}$ were observed between 14.12 and 14.15 for raindrops larger than $1.6 \mathrm{~mm}$ in diameter. This period corresponded to the time when the peak of echo intensity appeared near the ground as shown in Fig. 8, which is the time-height cross section of echo intensity just above the radar site. No raindrop with positive charge larger than $+0.25 \mathrm{pC}$ was observed from 14.23 to 14.52. Negative charge less than $-0.25 \mathrm{pC}$ was observed for raindrops larger than $1.6 \mathrm{~mm}$ in diameter from 14.38 to 14.39 , and from 14.43 to 14.45 . During these periods the peak of echo intensity appeared near the ground. On the other hand, no raindrop with negative charge less than $-0.25 \mathrm{pC}$ was observed from 14.53 to 15.26 . Positive charge larger than $+0.25 \mathrm{pC}$ was observed for raindrops with 1.8 $\mathrm{mm}$ in diameter from 14.53 to 14.55 , and at 15.10. During these periods the peak of echo intensity in the streak which was composed of raindrops from generating cell appeared at the radar site as seen in Fig. 8 .

Fig. 9 shows the number-size distributions. The number of negatively charged raindrops larger than $1.0 \mathrm{~mm}$ in diameter was larger than that of positively charged ones, and the number of negatively charged raindrops smaller than $1.0 \mathrm{~mm}$ in diameter was smaller than that of positively charged ones from 14.11 to 14.22 . From 14.23 to 14.50 the number of negatively charged raindrops was larger than that of positively charged ones for all sizes of raindrops. And the ratio of the number of negatively charged raindrops to that of positively charged ones decreased with decreasing diameter of raindrops. There seems no exact tendency in number-size distribution for the period between 14.52 and 15.25.

\subsection{CASE III (2.42 to 3.58 JST on 23 June)}

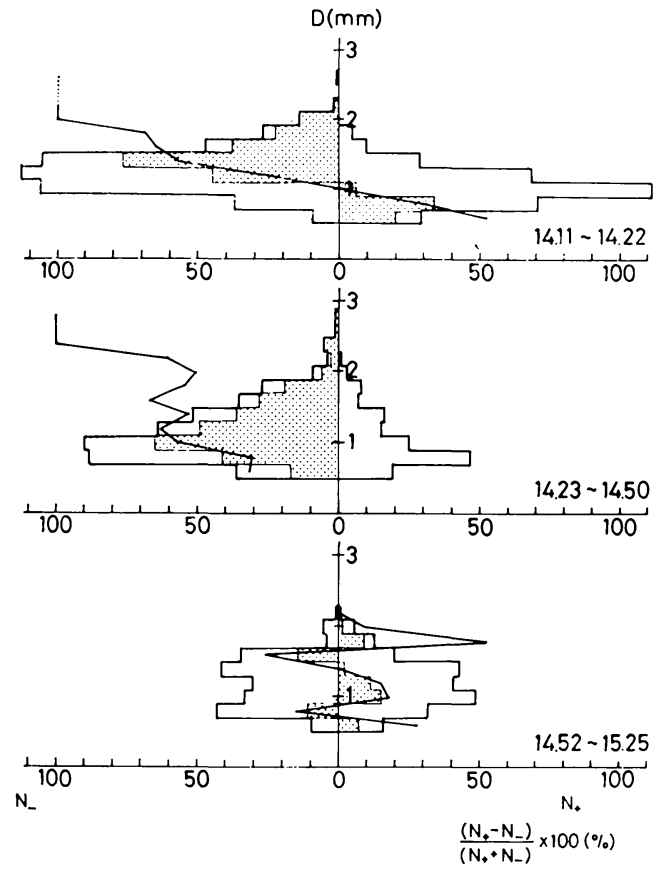

Fig. 9 Number-size distributions of raindrops for case II.

echo. intensity. Low-level convective clouds were observed in the early and the last stages of radar observation (from 2.00 to 4.14) as seen in Figs. $10 \mathrm{a}$, c and $\mathrm{d}$. The echo-top defined by $10 \mathrm{dBZ}$ was below the level of the bright band (4.5-4.75 $\mathrm{km}$ ). Middle-level echoes moved from the right to the left of the figure in the middle part of the observational period, and they were accompanied by streaks which entered the low-level convective clouds as seen in Fig. 10b. The middle-level echoes were quite weak, and the updraught in the generating cells would be weak. Raindrops observed in the middle part of the observational period were inferred to have been originated from both low-level convective clouds and middle-level clouds. 


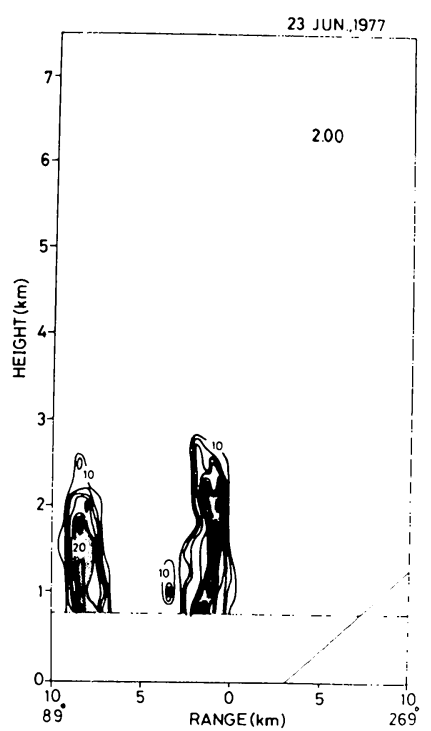

(a)

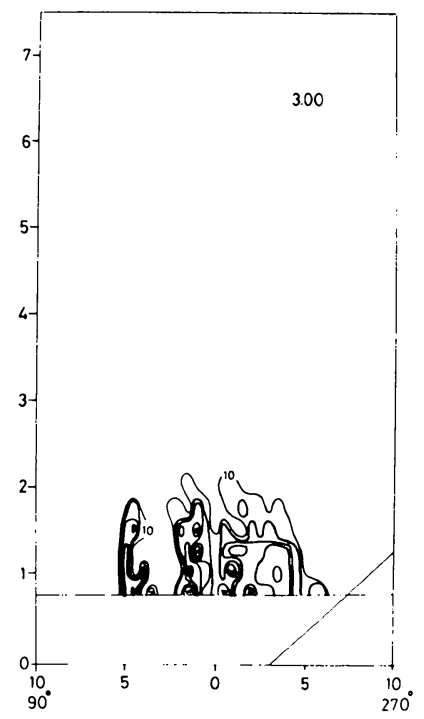

(c)

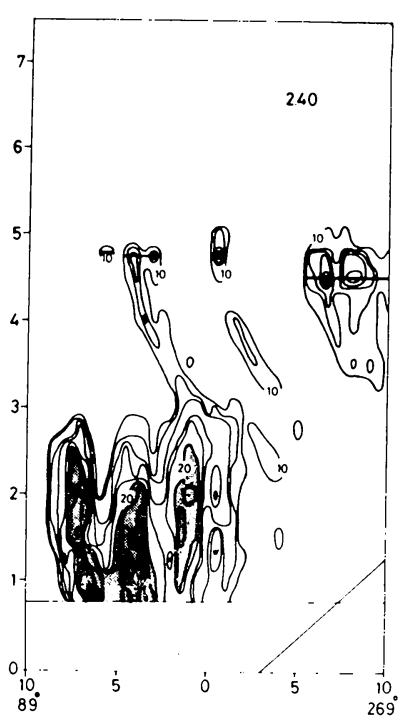

(b)

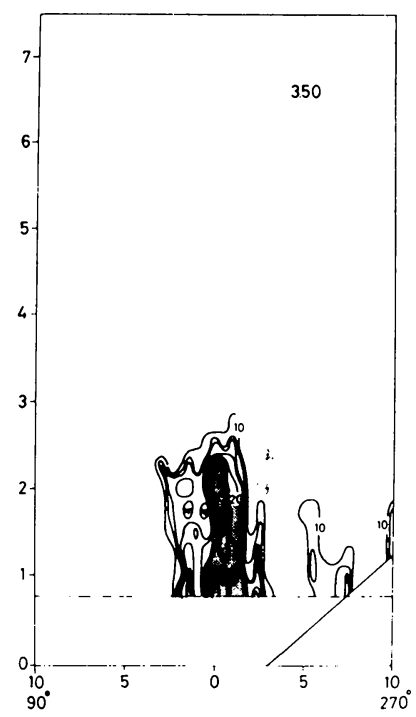

(d)

Fig. 10 Vertical cross sections of echo intensity for case III.

There was no record of electric field for this observation. Figs. $11 \mathrm{a}, \mathrm{b}, \mathrm{c}$ and $\mathrm{d}$ show changes with time of $I_{\mathrm{pr} .}{ }^{ \pm}, I_{\mathrm{pr} .}{ }^{\text {net }}, R$ and $\left(n_{ \pm}, n_{+}-n_{-}\right)$, respectively. Both positive and negative precipitation currents were large from 2.42 to 3.00 , and especially large from 2.42 to 2.50 . The sign of net precipitation current changed with time between 2.42 and 3.00 , but it was almost negative after 3.00. Although rainfall intensity was large, precipitation currents were small from 3.45 to 3.59 as seen in Fig. 11.
The charge-size distributions of raindrops in case III are shown in Fig. 12. The amount of charge on raindrops originated from low-level convective clouds (from 3.01 to 3.19 and from 3.35 to 3.58 ) was smaller than that from both low-level convective clouds and middle-level clouds (from 2.42 to 3.00 ). The amount of charge on drops observed between 2.42 and 3.00 was almost the same as that on drops originated from middle-level clouds in Figs. 3 and 7. This result indicates that even though raindrops originated 
(a)

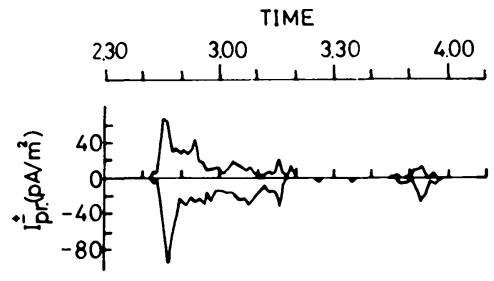

(b)

(c)

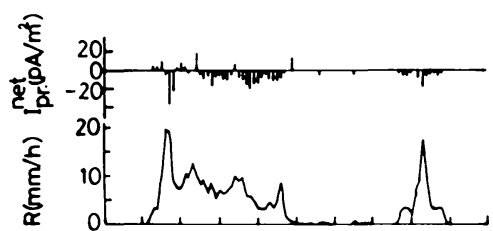

(d)

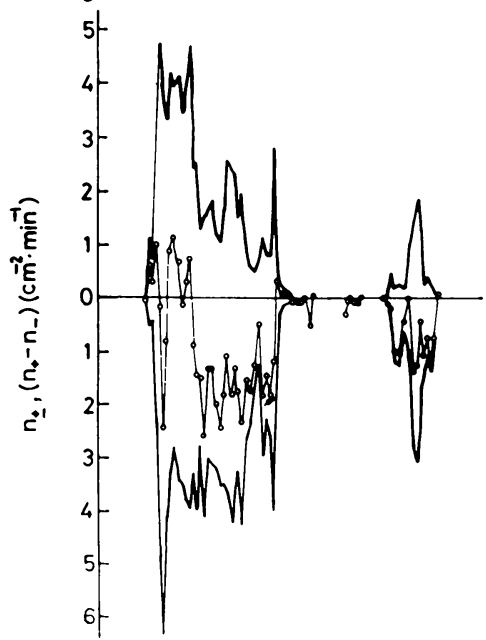

Fig. 11 Changes with time of (a) positive and negative precipitation currents, (b) net precipitation current, (c) rainfall intensity, and (d) the flux of the positively and negatively charged raindrops per $\mathrm{cm}^{2}$.

from middle-level clouds fell through low-level clouds, the amount of charge on raindrops did not change greatly. In contrast to CASE I and CASE II, there is no exact relation in chargesize distributions in Fig. 12. The amount of charge larger than $0.25 \mathrm{pC}$ was observed for raindrops with $2.8 \mathrm{~mm}$ in diameter from 2.45 to 2.46 as seen in Fig. 12. During the period intensive echo-region in the streak of the generating cell passed over the site as seen in the time-height cross section of echo intensity above the radar site (Fig. 13). During the period between 2.54 and 2.55 when intensive echo-region in another streak passed over the site, the sign of net precipitation current was positive as seen in Figs. $11 \mathrm{a}$ and $\mathrm{b}$. During the period between 3.35 and 3.58 negative charge less than $-0.25 \mathrm{pC}$ was observed only at 3.53 when most intensive

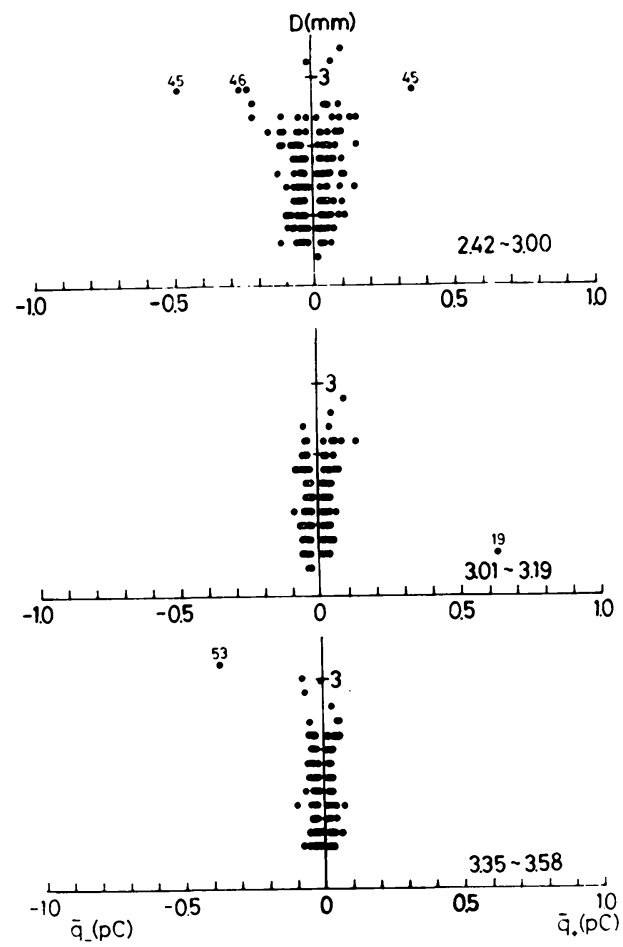

Fig. 12 Charge-size distributions of raindrops for case III.

echo-region of low-level convective clouds passed over the site in the period.

Total number of positively charged raindrops was larger than that of negatively charged ones from 2.42 to 2.54 as seen in Fig. $11 \mathrm{~d}$. In contrast, after 2.55 total number of negatively charged raindrops was larger than that of positively charged ones. Fig. 14 shows the number-size distributions. Unlike the number-size distributions in CASEs I and II, the percentage of the difference to total numbers of charged raindrops shows the maximum value at the diameter of 1.0-1.4 mm. Similar tendency was reported by Takahashi and Fullerton (1972) for raindrops in the case of warm rain. Although raindrops observed between 2.42 and 3.00 were originated from both middle-level clouds and low-level clouds, the number-size distribution in Fig. 14 resembles the distributions of raindrops originated only from low-level clouds. However, the chargesize distribution of raindrops observed from 2.42 to 3.00 does not resemble the distributions of both from 3.01 to 3.19 , and from 3.35 to 3.58 as stated before. These results indicate that most part of raindrops observed between 2.42 and 3.00 were originated from low-level clouds, and rain- 


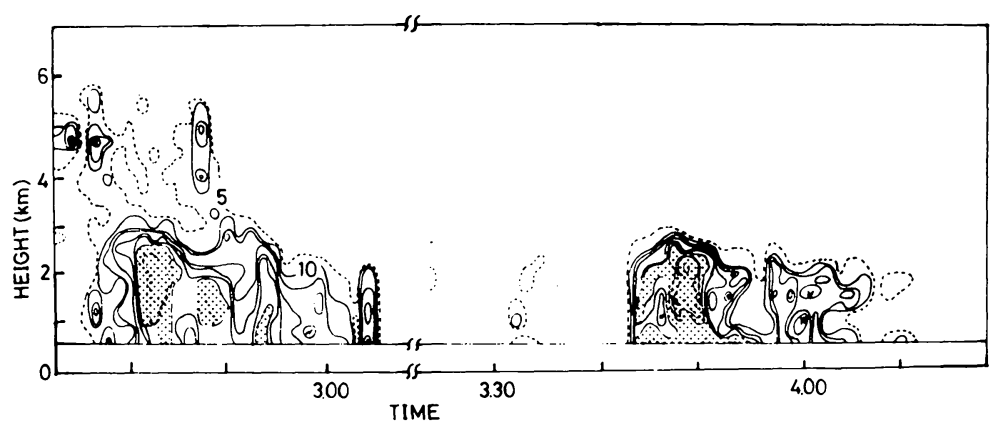

Fig. 13 Time-height cross section of echo intensity at the radar site.

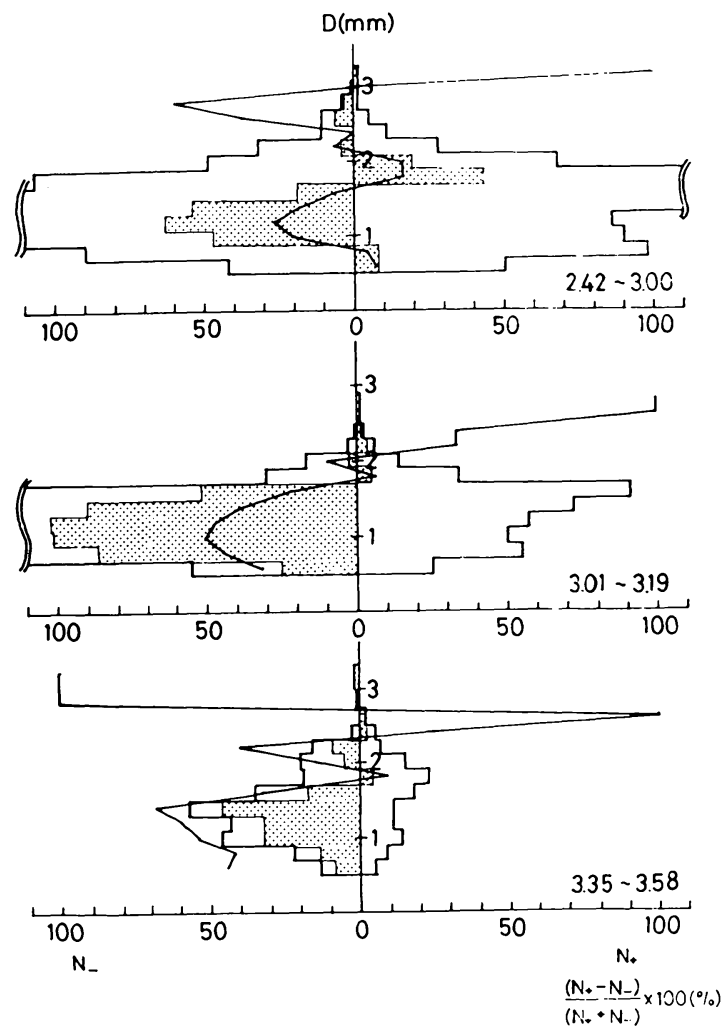

Fig. 14 Number-size distributions of raindrops for case III.

drops originated from middle-level clouds were small in number but large in the amount of charge on raindrops.

\section{Summary}

Observational results are summarized as follows.

CASE I: Precipitation particles were produced in generating cell above the freezing level, and melted into raindrops during their fall. Surface electric field was always negative. (1) When intensive echoes passed over the site of observation, most of large raindrops were charged negatively. The amount of charge on most of raindrops was less than $0.2 \mathrm{pC}$. However, raindrops with positive charge larger than $0.25 \mathrm{pC}$ were observed for almost all size-ranges around the periods when the peak of rainfall intensity appeared. (2) After the intensive echoes passed over the site, it rained lightly, and the charge on raindrops was less than $0.2 \mathrm{pC}$ for all sizeranges. Both charge-size and number-size distributions of raindrops did not show regular variation with size of drops except for the drops smaller than $1.0 \mathrm{~mm}$. The number of positively charged drops was larger than that of negatively charged drops for these small size-ranges.

CASE II: (1) Raindrops observed from 14.11 to 14.50 were resulted from melting of ice particles from layer clouds. Both surface electric field and net precipitation current were always negative during the period. Total number of negatively charged raindrops was larger than that of positively charged ones. The amount of positive charge was small almost independent of drop diameter, but the amount of negative charge increased with drop diameter. Almost all raindrops with large diameter were charged negatively. (2) Raindrops observed from 14.52 to 15.25 were resulted from melting of ice particles from small generating cells. Surface electric field was also negative during the period. The sign of net precipitation current changed with time. Number of positively charged raindrops was nearly equal to that of negatively charged ones for all size-ranges of drops. The amount of negative charge was small almost independent of drop diameter, but the amount of positive charge increased with diameter of drops. Raindrops with positive charge larger than $+0.25 \mathrm{pC}$ were ob- 
served when the peak of echo intensity in the streak passed through the radar site.

CASE III: (1) Raindrops observed from 2.42 to 3.00 were originated from both low-level convective clouds and small generating cells located above the freezing level. The sign of net precipitation current changed with time. The charge-size distribution did not show regular variation. During the periods when intensive echo-region in the streak from generating cells passed over the site, the amount of charge larger (or less) than +0.25 (or -0.25 ) $\mathrm{pC}$ was observed for larger raindrops. (2) After 3.01 we observed raindrops only from low-level convective clouds. The amount of charge on raindrops was smaller than that of drops observed from 2.42 to 3.00 , and the amount of positive charge on raindrops was nearly equal to that of negative charge on raindrops. Total number of negatively charged raindrops was larger than that of positively charged drops, and net precipitation current was negative in this period. (3) Number-size distributions show that the number-flux was the largest in the sizeranges from 1.0 to $1.4 \mathrm{~mm}$. The number of negatively charged drops was larger than that of positively charged drops in these size-ranges.

The amount of charge on raindrops observed in CASEs I, II and III was small in comparison with that observed in paper $I$. The raindrops whose charge was larger than $0.25 \mathrm{pC}$ were rarely observed. Raindrops with charge larger than $+0.25 \mathrm{pC}$ were not observed when they were originated from layer clouds as shown in CASE II. On the other hand, raindrops with charge larger than $+0.25 \mathrm{pC}$ were observed only when the intensive echo-regions in the streaks from generating cells passed over the site of observation as shown in CASEs I, II and III. Positive charge larger than $+0.25 \mathrm{pC}$ was observed only for raindrops larger than $1.6 \mathrm{~mm}$ in diameter in CASEs II and III, and those larger than $0.8 \mathrm{~mm}$ in diameter in CASE $\mathbf{I}$.

The amount of charge on raindrops originated from warm rain clouds was smaller than that from middle-level clouds. From the charge-size and number-size distributions of raindrops from both middle-level clouds and warm rain clouds, the amount of charge on precipitation particles from middle-level clouds was suggested not to be changed greatly when the particles fell through low-level convective clouds.

\section{Acknowledgements}

Thanks are due to Prof. T. Takeda, Water Research Institute, Nagoya University, for his advice and encouragement. To Prof. Y. Gocho, Disaster Prevention Research Institute, Kyoto University, we also acknowledge helpful discussions. We wish to express our hearty thanks to staff members of Owase Meteorological Station and Owase City Office for offering convenience to our observations. We are indebted to $\mathrm{Mr}$. K. Takase, Mr. S. Murabayashi and Mr. T. Ohtani for assisting our observations.

\section{References}

Bowen, E. G., 1951: Radar observations of rain and their relation to mechanism of rain formation. J. Atmos. Terrest. Phys., 1, 125-140.

Fujiyoshi, Y., T. Takasugi, Y. Gocho and T. Takeda, 1980: Radar echo structure of middle-level precipitating clouds and the charge of raindrops (I)-Processes of mixing of precipitation particles falling from generating cells-. J. Meteor. Soc. Japan, 58, 203-216.

and T. Takeda, 1980: Bright bands found out at different two levels simultaneously. (in Japanese) Tenki, 27, 29-34.

Harris, F. Ian., 1977: The effect of evaporation at the base of ice precipitation layers: Theory and radar observations. J. Atmos. Sci., 34, 651672.

Kikuchi, K., 1975: Atmospheric electrical properties of snow clouds with precipitation. J. Meteor. Soc. Japan, 53, 322-333.

Magono, C. and K. Orikasa, 1960: On the surface electric field during rainfall. J. Meteor. Soc. Japan, 38, 182-194.

Smith, L. G., 1955: The electric charge of raindrops. Quart. J. Roy. Meteor. Soc., 81, 23-47.

Takahashi, T. and C. M. Fullerton, 1972: Raindrops charge-size measurements in warm rain. J. Geophys. Res., 7\%, 1630-1636.

Wexler, R. and D. Atlas, 1959: Precipitation generating cells. J. Meteor., 16, 327-332. 


\section{中層降水雲のレーダーエコー構造と雨滴電荷 $(\mathbf{I I})$}

一一雨滴の電気的諸特性の变化一

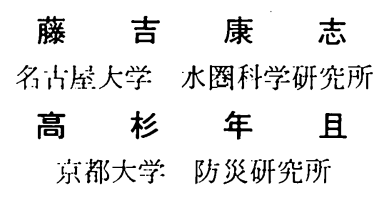

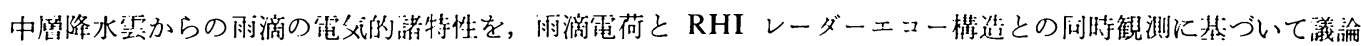
した。

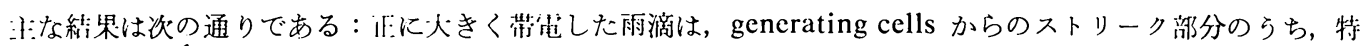

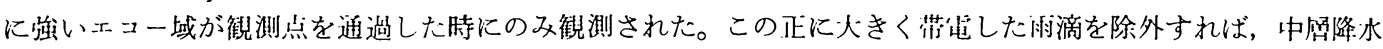

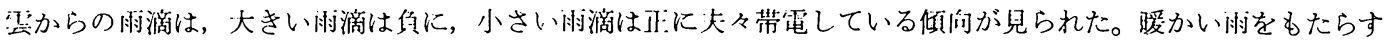

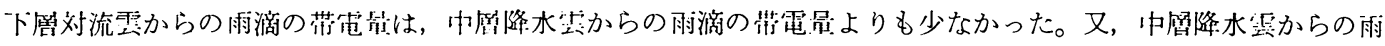

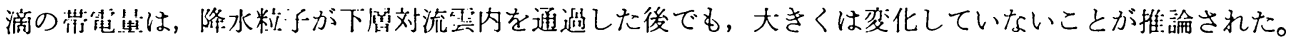

